\title{
Den romantiske sykdommen?
}

\author{
Det er mange unge døde i tuberkulosens kjølvann. Sykdommen har satt spor i bildende kunst, litteratur og \\ annen skapende virksomhet. «Piangi? Sto bene. / Pianger cosi, perchè? / Qui, amor... sempre con te!» synger \\ Mimì til en gråtende Rodolfo før hun synker inn i bevisstløsheten i siste akt av Puccinis La Bohème. Handlingen \\ foregår i et kunstnermiljø preget av lite penger, lite mat, dårlige boforhold, man brenner til og med manuskrip- \\ ter for å skaffe seg varme... I Tidsskriftet nr. 17/1936 drøfter dr. Nissen blant annet om det finnes en arvelig \\ komponent når det gjelder mottakelighet og om sykdomshyppigheten synker også fordi individer med \\ «uheldige gener» i mindre grad enn andre skaffer seg avkom (Tidsskr Nor Lægeforen 1936; 56: 942-50).
}

La Bohème spilles i Nasjonaloperaen fra 20.1. 2012.

\section{Bidrag til tuberkulosens epidemiologi.}

\author{
Av August J. Nissen, Østmarken sykehus, Trondheim.
}

Vi må gå ut fra som givet, at for at et smittet individ skal bli syk av tuberkulose må der to faktorer til, på den ene side tuberkelbacillen og dens virulens, på den annen side det smittede individs egen disposisjon. Som jeg før har omtalt, bør vi betrakte tuberkelbacillen som den invariable faktor i dette regnestykke, så meget mere som vi intet kjenner til at der foregår variasjoner i dens virulens. Disposisjonen varierer derimot sikkert fra individ til individ og hos det samme individ fra tid til annen. Det som denne forbindelse interesserer oss, er at disposisjonen varierer fra individ til individ. Hvilke kjemiske faktorer i cellene det er som betinger disposisjonen vet vi intet $\mathrm{om}$. Vi vet derimot at ytre faktorer kan påvirke disse kjemiske forhold og på den måten heve eller senke disposisjonen. Videre må vi ha lov til å gå ut fra at der ligger et meget sterkt virkende arvelig moment til grunn for den uhellsvangre disposisjon. For å resonnere videre ut fra det vi vet om arvelighet, må vi kunne si at der innen en befolkning forekommer gener som betinger disposisjon for tuberkulose, og gener som betinger motstandskraft mot tuberkulose. Tenker vi oss nu et slikt samfund med en passende blanding av uheldige og heldige gener og at tuberkulosen kommer til dette, vil man kunne forstå at de med uheldige gener blir syke og de med heldige forblir friske, selv om de smittes med Kochs bacille.

Jeg vil først henvise til fig. 1. Dette er den kjente grafiske fremstilling av tuberkulosedødeligheten sammenlignet med den øvrige dødelighet i Norge i 1924. Jeg minner altså igjen om det gamle velkjente faktum at tuberkulose er en ungdomssykdom. Dødelighetskurven har sin topp mellom 20 og 30 år. Ganske annerledes med den ikke tuberkuløse dødelighet, som vel forøvrig må tenkes å ramme så nogenlunde likt både individer med tuberkulosedisponerende gener og slike med tuberkulosemotstandskraftige gener. Man ser at denne dødelighet, bortsett fra spebarnsalderen, stiger med stigende alder og er

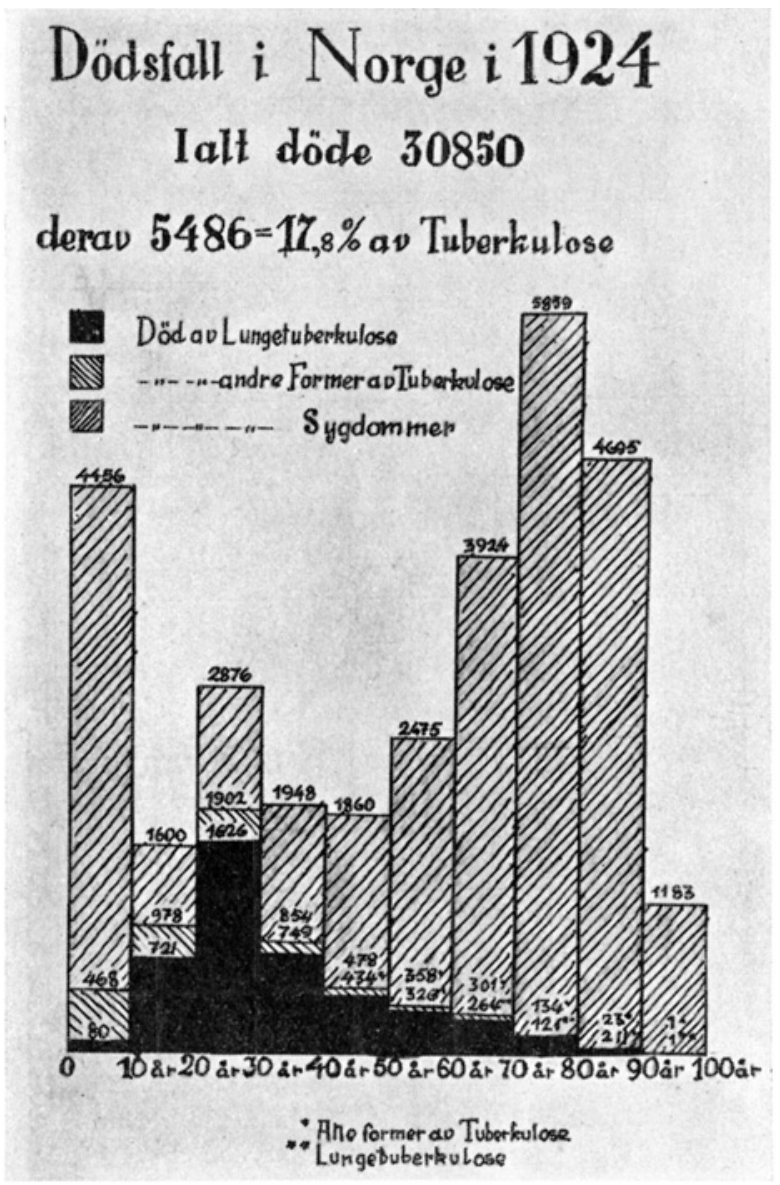

Fig. 1 .

ganske lav i de unge år. Det er altså ikke tvil om at en rekke individer med de tuberkulosedisponerende gener får sitt liv avbrutt $i$ ung alder og svært mange før de ennu har fått tid og anledning til å sette barn til verden. 